Facing a liturgy-starved church: do we need to think afresh about the basics of ministry?

\title{
Thomas O'Loughlin
}

Meet any group of Catholics today and within minutes someone will mention that their diocese / area is undergoing a 'reorganisation': parishes are being combined, the ordained ministers being spread more thinly around communities, and the access to gathering for eucharistic activity being curtailed. The process is sometimes given an elegant name derived from analogies with businesses that are down-sizing, but this does not hide the reality that this is driven by one key factor: fewer presbyters, aging presbyters, and there being little prospect that this situation - even with the addition of presbyters from Africa and India - any time soon. Speaking recently to a bishop in the midst of this process, I suggested that despite the glossy brochure about 'mission' and 'the future' which his diocese had produced, that if he could double the number of presbyters by some means he would reverse the process of closures. With admirable candour he replied that he would 'stop it in the morning!' Then he added with genuine frustration: but what can be done?

These reflections are an attempt to answer that question by suggesting that we need to think about the basics of ministry and not merely imagine that what has been the paradigm of ministry in the Roman Catholic Church since the early seventeenth century is neither set in stone nor in any way ideal:. Rather than being an ideal it was actually a pragmatic response to the Reformation which, in terms of Trent's vision of 'the priesthood' (a sacerdotium), was perceived as an officer-led rebellion that was to be prevented from recurring. These reflections make several theological and practical assumptions: First, that ministry is a function of belonging within the community of the baptised.

Second, that ministry is a response to the work of the Spirit within the whole community and with mutuality of skills within that community.

Third, that vocation is a reality within every Christian life and can include fixed ministerial tasks within the community, vocation can never be identified with those tasks. Fourth, real human communities - and so their liturgy - are nonfractal: they just cannot be 'scaled up' to accommodate a 
shortage of any one kind of ministry. In forming real communities in which the members experience belonging, there is a maximum size before the grouping becomes merely an administrative division for which individuals may still feel tribal loyalty, without any committed belonging.

Fifth, the central action of Christian liturgy, the eucharist, is, in its fundamental form, a specific case of this non-fractality.

Because it is the meal of a community of the baptised who form, in Christ, a fictive family gathered as his friends around the common table, it cannot be simply scaled-up without being transformed in the experience of those taking part into another form of religious gathering.

And lastly, given that gathering around the Lord's Table is at the centre and summit of the community's activity, all ministry

within that gathering is a function of it, rather than the eucharist being a function of some other ecclesial structure. Put simply, we should be able to find as many presiders as we have real eucharistic communities, rather than seeking to form eucharistic gatherings in response to the number of available presbyters.

\section{Liturgical ministry}

At first sight, the issue of 'liturgical ministry' would appear to be simple. Every religion, and every Christian denomination, has religious leaders, and these take the leading roles at its rituals. Thus we talk about 'priests' in various religions, and even in a religion like Islam where the term has no strict meaning, we still speak about 'Moslem clerics.' Moreover, ritual requires expertise, and the amount of expertise required is usually a direct function of the length the group's remembered tradition: these experts, nowadays usually formally trained, are its liturgical ministers. Thus a presbyter in an Eastern Orthodox church needs to know about a complex ritual harbouring elements that have grown up over a period of perhaps 1700 years; while the leader of a contemporary western evangelical church, while eschewing any inherently sacral status, still needs to claim special expertise as a biblical teacher. While for us Catholics, we deem seven years of formation as necessary lest we be short-served. Such expertise is then seen as the empirical basis for ministry (either parallel with or apart from some notion of authorisation such as 'ordination'), and then those experts 'minister to' the other church-members, by either carrying out the rituals, leading the group in its liturgies, or acting as its teachers during worship. In each case 
there is a binary model at work: a sole minister or small ministrygroup which acts, leads and preaches / speaks / teaches on one side, and opposite them a much larger group which attends / listens / and receives ministry. We see this model in a nutshell in the phrase: 'the clergy administer the sacraments' or the funny pub-sign with the parson alongside other functionaries and the label: 'I pray for all.' This is a valuable and widely appreciated model because it fits well beside other expert service providers in society (e.g. medics providing healthcare to the rest of the community or accountants providing financial services), and, therefore, full-time 'ministers of religion' are aligned by society, and often by themselves, with those other experts. And indeed, trained ministers do have a great deal of expertise, honed by experience, in comparison with most other church members, and this, coupled with a service ethos, thrusts them into leadership positions such that ministry takes on the shape of 'active' giving by leaders, while the rest are 'passive' receivers. The dynamics of ministry in the liturgical space are, therefore, not unlike the dynamic of actors / audience in a theatre: each are participating, one group by giving a performance, the other by receiving and responding to it. Moreover, in society many tasks are carried out on behalf of the whole group by a specialist cadre (e.g. politics or policing) and the small group acts with deputed authority; and a religious variant of this can be found in the notion of a 'priesthood' / a 'clergy' in many religions which have a specialist temple personnel (e.g. the Levites in ancient Jerusalem). Thus because society needs a 'chaplaincy' service; and we have a justification of clergy and of their liturgical ministry within society. This kind of justification for ministry is now rarely proposed by Christians when living in multicultural situations, but was widely used when they imagined their societies as homogeneously Christian or Catholic - and it is still far more influential both among those who reject the Church and those who pine for lost era of church-centrality than is often recognised.

\section{Discipleship as community service}

In stark contrast to such highly structured notions of ministry or priesthoods, Christians have the memories of the first disciples of Jesus. Jesus was not a Levite, his ministry barely engaged with the formal religious expert systems, and when those structures are recalled (e.g. Lk 1031 and 32; Jn 4:21), they are the objects of 
criticism or presented as transient. Moreover, while Jesus was presented as appointing messengers / preachers (apostles) there is no suggestion that these were thought of as ritual experts. And, while leaders emerged in the various early churches (with a variety of names: e.g. 'elders' [presbuteroi] or 'overseer-servants' [episkopoi kai diakonoi] which was originally a double-name for a single person, but which later on would divide into two ranks: 'bishop' and 'deacon'), it took generations (until the later second century - in contradiction of older textbooks we know now that Ignatius of Antioch wrote after 160 at the earliest) for those patterns to be harmonised between communities and then systematised into authority structures. There is no suggestion in the first-century documents that leadership at the two key community events, baptism and eucharist, was restricted in any way or the preserve of those who were community leaders, much less a specially authorised group. The link between (a) leadership of the community and (b) presidency at the eucharistic meal (a linkage that would drive much later thinking on ministry and even today is a major source of Christian division) would not be forged until the third century, and only later again would 'the history of its institution' by Jesus be constructed. Even more explicit was the remembered teaching upon leadership in the community where there was to be radical equality among church members, for example in this story:

And Jesus ... said to them, 'You know that those who are supposed to rule over the Gentiles lord it over them, and their great men exercise authority over them. But it shall not be so among you; but whoever would be great among you must be your servant, and whoever would be first among you must be slave of all' (Mk 10: 42-4).

This vision of equality is also found in the third 'do this' story in the gospels (the other 'do this' commands relate to baptism and the eucharist) in Jn 13:3-15 where the relationship of leaders in the community is modelled on that of washing the diners' feet by Jesus (a task normally done by the lowest rank of female slave). Significantly, this action, despite the injunction in Jn 13:15, did not develop into a regular community practice! The followers of Jesus were to be (in two early second-century documents) a 'priestly people' (1 Pet 2:9: 'a priestly kingdom' / basileion hierateuma) where all shared by baptism in Christ who was uniquely their priest (hiereus) (Heb 2:17). 
This tension between the empirical need for organization within groups, coupled with the fact that power tends to concentrate and to be seen as a sacral faculty - a development facilitated by using a combination of Old Testament models and terminology and cultural assumptions taken from Greco-Roman culture: e.g. 'pontifex' or 'ordo'), on the one hand, and the memory of what distinguishes the new priestly people in Christ where ministry was both more embracing (the whole community is the minister) and less structured (each can potentially take on any service for the others) can be seen as underlying all the later disputes about ministry and priesthood. Those disputes - and the still continue for many Christians - were made all the more intractable by the conviction on each side, in each dispute, that an explicit answer could be derived from their authoritative foundational sources!

It has long been an illusion of the various Christian denominations that a study of history - and particularly the first couple of centuries or the texts from those times they held to belong to the New Testament Canon - could provide either a blueprint for ministry (e.g. 'the three-fold structure of order': bishop, presbyter, deacon) or an conclusive answer to issues relating to ministry that have arisen in later situations (e.g. what 'power' can be seen as coming from Christ to the priest at the time of the Reformation, or can a woman preside at the eucharist today). This is an illusory quest for not only does it fall victim to the anachronism inherent in all appeals to a perfect original moment, a much imagined period in the past when all was revealed (at least in nuce); but it assumes that ministry as it later developed was not itself the outcome of multiple, often conflicting, forces in the particular societies, as well as adaptations by Christians to well-known inherited religious structures. So, for example, the clerical system, within which was/is located liturgical ministry, for much of Christian history related originally to the political needs of the church as a public body within the Roman Empire; and as that imperial society had highly organised priesthoods, so people took it for granted that similar groups would exist in the Church. Likewise, the monastic elements that became linked with liturgical ministry can be seen as a result of the place of monasticism as the ideal of holiness in late antiquity; while the notion of 'hierarchy' (i.e. sacred power descends through intermediaries from higher to lower levels of reality: such that the holier leader [the 'hierarch'] offers sacrifice 'on behalf of' or 
performs liturgy for the others as an effect of his special election and superior powers) can be seen as the result of fitting Christian theology within a Neoplatonic world view within rigidly-layered social environment.

Given that there was no 'original' plan for liturgical ministry in the church, and as a result of centuries of disputes there are many conflicting views what constitutes someone within ministry, it is quite impossible - except within the mythic spaces of particular denominations - to produce a systematic basis for liturgical ministry. However, given that ministry occurs and is needed, one can set out some criteria that can help individuals and communities to develop a pragmatic theology of liturgical ministry.

\section{Criteria for ministry}

A balanced approach, both in practice and theologically, needs to take account of several factors.

a. Any specific ministry is a variation on baptismal belonging

First, every specific ministry is a particular variation of the ministry of all the baptised, and in baptism there is a radical equality: 'there is neither Jew nor Greek, there is neither slave nor free, there is neither male nor female; for you are all one in Christ Jesus' (Gal 3:28). This radical equality is a characteristic of the new creation brought about in Christ; therefore, any subsequent distinctions such that particular ministries are not potentially open to every baptised person are tantamount to a defective theology of baptism by which all ministry is brought into being. It is baptism that constitutes the people who manifest the work of the Christ in the world.

Therefore, making further demands for 'signs' of particular divine election (e.g. being able to speak in tongues or handle snakes) as indications of suitability for ministry fly in the face of the incarnational dispensation seen in baptism. Likewise, regulations that restrict ministry to particular states of life (e.g. demanding celibacy as a condition for the presbyterate in the Roman Catholic church or for the episcopate in the Orthodox churches) have to be seen as a undue concern with the status of certain ministries implying that baptism is merely some basic 
entry requirement for 'Christianity' rather than that which creates the new person who can minister, and in that new creation no such distinctions exist. Similarly, the notion that women, as such, can be excluded from ministry on the basis of some pragmatic historical appeal (e.g. 'Jesus did not ordain women!' - assuming such a pre-critical view of 'history' has any value), fails to take account of the fundamental role of baptism in all Christian existence and action. The slogan "if you cannot ordain 'em, your shouldn't baptise 'em" may seem crude, but it does capture the fundamental insight that incorporation into the risen Christ (i.e. baptism) is the source of all liturgical ministry and of every particular act of liturgy.

\section{b. All ministry is Christ-ian}

Second, it must respect the awareness that all action and ministry by Christians is Christ-ian in nature. Christians form a people, they are not simply a collection of individuals, and this is a priestly people because it acts in union with its unique High Priest, Jesus. It is the work of the Christ in blessing the Father that constitutes the reality of liturgy of the New Covenant, and the worship of the disciples is only Christ-ian liturgy in so far as it is through, with and in Jesus. So individuals do not offer praise and petition except as part of the community, and the community only does so in so far as it acts in Christ. This fundamental dynamic becomes actual in the liturgy of particular gatherings. It is as a church, a real community, that we gather to celebrate our common meal of thanksgiving, and it is the church which blesses the Father. This desire of the assembly is given voice by the one presiding within the community, and this prayer of thanksgiving is made in, with, and through Jesus who makes us his people in the presence of the Father.

We all too often, and too easily, loose sight of the fact that Christians must think of their liturgy in a way that is radically opposed of that commonly found other religions of a 'religious service' due to God or the gods. In that paradigm, the divine is the opposite of the world in which we live and to which something is owed, presented, transferred, and this constitutes a mode of contact with the divine realm, which might constitute a debt of loyalty / praise / petition or appeasement. Making this connection, whether by an individual or a group, assumes a technical knowledge and some sacred skill - usually the work of a 
special priesthood - such that the divine recognises that the action performed is the appropriate sacred deed. Christians, contrariwise, conceive their worship on the basis that their priest has come to them and is with them as a community. Therefore, where two or three are gathered in the name of Jesus, he is with them (Mt 18:20), and so their actions together - such as celebrating a meal - take place in presence of the Father, because Christ, present among them, is always their High Priest. This theological vision has important implications for individual Christians who find themselves performing specific acts, ministries, within the Church.

Firstly, professional Christian 'ministers' need to remember that although in common perceptions they will be seen as the 'religious service experts' and seen as yet another variant of the religious phenomenon of 'priests' (a word designating sacred functionaries in most world religions - and studied as such in religious studies), this is not a good starting point for their own self-understanding. Christian history has too much distracting baggage resulting from its ministers taking over their understanding of their role within the Church by analogy with the role of priests (sacerdotes), temples, and sacrifice in both the Old Testament and Greco-Roman religions. Within Christianity, the ministry is that of the whole community - and so for that matter every Christian can, and perhaps should, own the designation 'minister of religion' - the difference between any two Christians (even if one has the most gaudy liturgical wardrobe and uniform, while the other wears none) is only a matter of external perception, accepted learned skills, and designated functions within the community. Secondly, it is worth remembering that language plays us false in understanding 'priestly ministry' in particular. The Old Testament the 'cohen' (which we render by the word 'priest') performed special tasks - as a matter of divine appointment - on behalf of the rest of Israel (see Leviticus and Numbers). This was rendered in the Septuagint by the word hiereus - a word commonly used for pagan temple officials - and then, later, into Latin by sacerdos which was a generic word covering all the various special temple 'priesthoods' such as flamenes and pontifices. The early Christians did not use these word for their leaders: hiereus / sacerdos belonged to Jesus alone in the heavenly temple. Christian leaders were designated by their relation to the community: as the one who oversaw, led, or served it. Later, the hiereus / sacerdos language was absorbed 
and became the basis of Christians' perceptions of their presbyters. So our word 'priest' is etymologically from the word 'presbyter', but conceptually it relates to the sacerdotal functions. One consequence of this is that those so designated think of themselves as 'ministers of God' - they perform a service to Him - but it is the community in Christ that is the minister of God, and specific individual functionaries, such as presbyters, are ministers to the community. Thirdly, another consequence of Christian officials taking over a sacerdotal self-understanding was they explained their work (by parallel with Old Testament cohenim) in terms of its distinctiveness from that of the rest of the baptised, or as did pagan priesthoods (sacerdotia) as being specialists acting on behalf of ordinary people. Once this had occurred they had to ask what made them different and what special religious quality did they have which others did not possess: the answer came with the notion of a power 'to consecrate,' and then this power (itself the subject of rhetorical inflation) became the basis of 'ontological difference' between them and 'ordinary Christians,' or between their 'ordained priesthood' and a nebulous, and often ignored, 'common priesthood.' Not only is this 'priesthood defined by difference' theologically flawed, but it obscures the unique role of the Christ in Christian liturgy, it downplays the role of the Church as 'the people of God,' and it creates a 'two-tier' Christianity of the special religious people (e.g. clergy / monks / nuns) and passive 'other ranks' whose ministry is 'praying, paying, and obeying.'

After more than a millennium and a half of these confusions in Christianity, both east and west, it is very hard for many who see themselves as 'ministers' in a church - especially those with elaborate sacerdotal liturgies - to break free of this baggage. But for all its complex, gilded splendour, it is still a distracting deviation from core Christian beliefs. Meanwhile, some churches continue to evolve in its wake (e.g. the recent declaration by the Catholic Church that women are absolutely excluded from the presbyterate), while being conceptually cognisant of the problems of imaging ministry in terms of a distinct sacerdotium. Tradition can be like a great oil-tanker turning at sea: it takes a long time to overcome inertia, and for the ship to answer the helm!

b. Ministry is actual service not potency 
Third, one of the thorniest questions that beset discussions, particularly between denominations, about ministry concerns the issue of authorization. This usually presents as a discussion about 'ordination' within a sacerdotal model of 'priesthood' such as we have just examined. In such a model the priest must be thought of in terms of some specific 'power' and since this, unlike that of the Levites, does not come with birth, it must come from a specific act of empowerment: 'ordination.' Ordination, in turn, comes to be seen as an act of 'making something.' In such a situation a person is either 'the thing made,' or not. So discussions between churches either ignore the issue (which renders the discussion little more than polite window dressing) or search to validate each other's 'orders' (which becomes a matter of arcane history and black/white answers). Such starting points only promote deadlock.

A far better approach is to note that all groups need, at least, some formal organisation, while Christians must also work with one another in communities (they claim to be called to love one another), and, then, to treat each such community as a basic church. Next, enquire if the ministry structures are adequate to helping them to pray together, to receive teaching that promotes understanding and discipleship, to keep them together as a group, to answer specific needs a group might have (e.g. poor, old, young families), and ensure that the ministers do not behave in a tyrannous (as can happen all too easily in ministry) or an abusive (it is easy for 'religious authorities' to take advantage of the trust given them) or a self-serving (a problem already noted in the mid-first century) manner. Whoever fulfils these needs and functions should be seen as 'the ministers' of that community, and respected as such by other churches and groups of ministers. The differences in the styles and structures can be considered subsequently as part of the varied tapestry of the work of the Spirit and historical circumstances - and they can learn from one another which elements from the others' visions of ministry they might import - and which of their own they need to change or drop!

\section{c. Service requires skills}

Fourth, most specific expressions of ministry to the community require some level of skill and this, given the way humans develop, will be the result of ability, experience, and training. 
Many churches are not far beyond the older position whereby if one passed an academic course in theology or was deemed 'fit for orders,' then training in liturgical ministry was but a practical after-thought. And in traditional societies where 'going to church' was part of the week, few cared whether or not a minister had any sensitivity to leading people in liturgy. However, an adequate view of liturgy, and the nature of contemporary Christian belonging, requires far more awareness of the skills needed for this ministry. Thus someone presiding at the eucharist needs to have the skills of a host at a great celebratory meal; and if that is a task that fills them with dread (note the number who fear such roles at weddings, for example), then that person should not be called on to preside and give voice to the community. Likewise, someone who dislikes public speaking or lacks aptitude as a teacher will find preaching difficult - and this cannot be remedied by training in 'communication skills'. A basic ministry skills in most communities today is the ability to lead spontaneous prayer - which needs great sensitivity and some of the art of the poet so someone who lacks this skill is not someone who, simply in virtue of ordination, presumes to be able to lead a community in its prayer. By contrast, those who are good communicators are often poor listeners, and so they will not be so good in ministries of reconciliation. And while we can all benefit from growing in sensitivity for those who are suffering, a ministry of healing will fit best with someone with 'a bedside manner.' We should see the Spirit empowering each community with the variety of skills it needs, and then aligning each individual's skill to the necessary tasks as the work of ecclesial vocation. After such alignment, formal training (always valuable given the haphazard way humans absorb information) is a case of organising, developing and drawing out charisms latent in the individual as a member of the community. So rituals like ordination should be seen as actualising and recognising gifts already within the church from the work of the Spirit, rather than the conferring of 'powers' extrinsic to the person.

Moreover, liturgical ministry is not a matter of holes and pegs. Rather, it is a community recognising its needs in Christ, and of individuals deploying, creatively, their range of gifts, insights, and skills (a mix unique to each person) in the service of their church. Each liturgical ministry should actualise that person's distinctive contribution to a unique moment in Christian history. Liturgical ministry is an art as much as a skill or a 'vocation.' 
The standard one-size-fits-all model of the cleric (usually chosen for other criteria than liturgical ministry) who in virtue of 'ordination' carries out every ministry cannot be justified either theologically (for it ignores the Spirit's workings in an actual church) nor practically as no individual can be presumed to have that skill-range nor be able to deploy such adaptability on a day to day basis. A deeper awareness of the needs of liturgical ministry leads to basic questioning of most ministry training models - many denominations are still too content with that of 'the one-person show' - and this is a major challenge facing churches today.

e. Ministry is not equivalent to management

Fifth, churches grow, and often become vast international organisations with consequent management needs - and our own Church is the case par excellence. Down the centuries it has been assumed that those chosen for their skill in liturgical ministry would automatically have management ability (at least at local levels), and it has always been assumed that those with the widest administrative duties would be the most senior liturgical ministers - and sometimes this has been the case! However, just as there are varieties of skill within liturgical ministry, so liturgy as the Christ-ian expression of the community is different from church management, and, consequently, there is a difference in the abilities needed between those who perform specific tasks in each sphere. In those churches with highly structured linemanagement, it is often the case that the leaders, usually bishops 'with the power of jurisdiction,' are also expected to be able to take the lead in liturgy - and this is not a problem if liturgy is seen just as a derivative of 'the power of order.' However, experience often shows that such managers (and such are needed) are not those who can either teach adequately or lead worship effectively; and the converse situations are also true: a good academic or a sensitive pastor of small community may turn out to be a useless bishop. A deeper consciousness of such problems - and they come to light most clearly when we consider liturgical ministry - inevitably leads to an awareness of the need in most churches for them to consider afresh the whole set of interlocking structures that come with bounds of 'church ministry.' 


\section{Where do we start?}

In every community there are those who have the skills that have brought that group together and given it an identity. This, in ecclesial terms, reflects the silent working of the Spirit gathering the scattered individuals and transforming them into the body of the Christ. So the task is to recognise these actual ministers and to facilitate them to make that ministry more effective and fruitful. Some will have the gifts of evangelizing and welcoming, others the skills of leading in prayer and the offering of the thanksgiving sacrifice of praise, others the gifts of teaching, others of reconciling, others for the mission of each community to the building up of the kingdom of justice and peace, and some will have the management skills to pay the bills. None is greater and none is less - a shocking idea to most Catholics but no more than the Johannine vision of mutual ministry set in the climactic moment of the Last Supper.

In every discussion of ministry we need to keep having the advice of Paul to the church in Corinth in 58 C.E. echoing in our heads as he presents ministry as the working out the presence of the Spirit in the assembly:

Now there are varieties of gifts, but the same Spirit; and there are varieties of services, but the same Lord; and there are varieties of activities, but it is the same God who activates all of them in everyone. To each is given the manifestation of the Spirit for the common good. To one is given through the Spirit the utterance of wisdom, and to another the utterance of knowledge according to the same Spirit, to another faith by the same Spirit, to another gifts of healing by the one Spirit, to another the working of miracles, to another prophecy, to another the discernment of spirits, to another various kinds of tongues, to another the interpretation of tongues.

All these are activated by one and the same Spirit, who allots to each one individually just as the Spirit chooses. For just as the body is one and has many members, and all the members of the body, though many, are one body, so it is with Christ. For in the one Spirit we were all baptized into one body Jews or Greeks, slaves or free - and we were all made to drink of one Spirit (1 Cor 12:4-13). 
Sometime later in the first century when the followers of Jesus were coming to grips with the religious earthquake of the destruction of the temple in Jerusalem, one of Paul's followers reframed that vision in terms of each ministry being the gift of the risen and ascended Christ present in each community:

The gifts he gave were that some would be apostles, some prophets, some evangelists, some pastors and teachers, to equip the saints for the work of ministry, for building up the body of Christ, until all of us come to the unity of the faith and of the knowledge of the Son of God, to maturity, to the measure of the full stature of Christ (Eph 4:11-13).

If we these statements reverberated through our discussions today we might need to talk less about 'closing churches' and 'combining parishes' and could then move on to the more fruitful task of discovering the wealth of vocations that are all around us. But there is only one [merely logical] certainty: the future will not be like the past; and when a present seeks to recede into its past, it is untrue to its own moment. 